Canadian

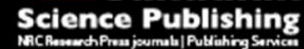

Canadian Journal of Microbiology Revue canadienne de de microbiologie

\title{
Using micro-patterned surfaces to inhibit settlement and biofilm formation by Bacillus subtilis
}

\begin{tabular}{|r|l|}
\hline Journal: & Canadian Journal of Microbiology \\
\hline Manuscript ID & cjm-2016-0463.R2 \\
\hline Manuscript Type: & Article \\
\hline Date Submitted by the Author: & 09-Mar-2017 \\
\hline Complete List of Authors: & $\begin{array}{l}\text { Chang, Siyuan; Key Laboratory for Thermal Science and Power } \\
\text { Engineering of Ministry of Education, Department of Thermal Engineering } \\
\text { Chen, Xiaodong; Suzhou Key Lab of Green Chemical Engineering, College } \\
\text { of Chemistry, Chemical Engineering and Material Science } \\
\text { Jiang, Shuo; Key Laboratory for Thermal Science and Power Engineering of } \\
\text { Ministry of Education, Department of Thermal Engineering } \\
\text { Chen, Jinchun; Lab of Microbioly, School of Life Sciences } \\
\text { Shi, Lin; Key Laboratory for Thermal Science and Power Engineering of } \\
\text { Ministry of Education, Department of Thermal Engineering }\end{array}$ \\
\hline Keyword: & \begin{tabular}{l} 
Biofilm, B. subtilis, Micro-patterned surfaces, Bacteria settlement \\
\hline
\end{tabular} \\
\hline
\end{tabular}




\title{
Using micro-patterned surfaces to inhibit settlement and biofilm formation by Bacillus subtilis
}

Siyuan Chang1, Xiaodong Chen ${ }^{2}$, Shuo Jiang ${ }^{1}$, Jinchun Chen ${ }^{3}$, Lin Shi ${ }^{1}$

\begin{abstract}
Affiliation and address:
${ }^{1}$ Key Laboratory for Thermal Science and Power Engineering of Ministry of Education, Department of Thermal Engineering, Tsinghua University, Beijing, P.R. China

${ }^{2}$ Suzhou Key Lab of Green Chemical Engineering, School of Chemical and Environmental Engineering, College of Chemistry, Chemical Engineering and Material Science. Soochow University, Jiangsu Province, P.R. China

${ }^{3}$ Lab of Microbiology, School of Life Sciences, Tsinghua University, Beijing, P.R. China
\end{abstract}

\section{E-mail addresses:}

Siyuan Chang: changsiyuan1226@163.com

Xiaodong Chen: xdchen@mail.suda.edu.cn

Shuo Jiang: jiangxlp@163.com

Lin Shi: rnxsl@mail.tsinghua.edu.cn

Correspondence: Lin Shi; Professor; Department of Thermal Engineering, Tsinghua University, Beijing, 100084, P.R. China; Tel: +86 010-62787613; Fax: +86 010-62787613; E-mail: rnxsl@mail.tsinghua.edu.cn

1 
Abstract: Biofilm is a biological complex caused by bacteria settlement to the substrates, their subsequent reproduction and secretion. This phenomena reduce heat transfer efficiency and cause significant losses in treated sewage heat recovering systems. This paper describes a physical approach to inhibit the bacteria settlement and biofilm formation by Bacillus subtilis, which is the dominant genera in the treated sewage. Here, the micro-patterned surfaces with different characteristics (stripe and cube) and dimensions (1 $\mu \mathrm{m}$ to $100 \mu \mathrm{m}$ ) were fabricated as surfaces of interest. Model sewage was prepared and a rotating coupon device was used to form the biofilms. Precision balance, scanning electron microscope (SEM) and confocal laser scanning microscope (CLSM) were employed to investigate the inhibitory effects and the mechanisms of the biofilm-surface interactions. The results have shown that surfaces with small pattern sizes $(1 \mu \mathrm{m}$ and $2 \mu \mathrm{m})$ all reduced biofilm formation significantly. Interestingly, the CLSM images showed that the surfaces do not play a role in 'killing' the bacteria. These findings are useful for future development of new process surfaces on which bacteria settlement and biofilm formation can be inhibited or minimized.

Keywords: Biofilm / B. subtilis / Micro-patterned surfaces / Bacteria settlement 


\section{Introduction}

Treated sewage is in huge quantity in modern society. It is an important carrier of urban waste heat energy (Chan et al. 2009). Its temperature $\left(20-30^{\circ} \mathrm{C}\right)$ is ideal for maintaining high efficiency for heat pump operations (Meggers and Leibundgut 2011). Treated sewage source heat pump systems (TSSHPS) reuse the low-rank energy in the treated sewage to provide heat and cold for buildings (Yang et al. 2013), and practical projects such as the 2008 Beijing Olympic Village TSSHPS have been proven to be efficient (Tian et al. 2012a). However, the treated sewage contains "impurities" such as bacteria, which can form biofilms in the plate heat exchangers in the TSSHPS (Yang et al. 2015). Previous studies have also shown that considerable biofilms were formed in the heat exchangers within 40 days of operation and reduced the heat transfer coefficient by 60\% (Murthy et al. 2004; Tian et al. 2012b).

Biofilm, a complex community of microbes attached to a solid surface and encased in extracellular polymeric substance (EPS), could be used for root protection or pollutant removal (Haggag and Timmusk, 2008; Chug et al. 2016). However, in some other cases, biofilms could lead to efficiency decrease of heat-exchanging systems, and compromise safety in food processing and medical instruments (Steinhagen et al. 1993; Cartwright and Spurr 1998; Dahlström et al 2004; Vinh and Embil 2005). Biofilms are formed by bacteria and/or other microorganisms attaching to biotic or abiotic surfaces and then forming microbial colonies and encased in the EPS. (Galván et al. 2016). Studies have shown that the biofilm structures protect indwelling organisms from physical and chemical 'attacks', including oligotrophic environment, flow erosion and high concentration of bactericides (Stoodley et al. 2001; Dolan and Costerton 2002).

In the interest of reducing biofilms, innovative inhibition and eradication strategies are constantly being sought (Mah and O'Toole 2001; Joshi et al. 2009). Among these strategies, micro-patterned surfaces have been found to reduce bacteria settlement and cause no harm to the environment (Callow et al. 2000; Baier 2006; Scardino and de Nys 2011). Some biomimetic surfaces with micro-patterns have been developed and their ability to inhibit the microorganism settlement 
explored (Vejborg and Klemm 2008). Metal surfaces with nano-scale topographies have been processed and found to mitigate biofilm formation through the bactericidal effects (Sapkota et al 2011). Several commercial micro-patterned polydimethyl siloxane (PDMS) surfaces have also been reported to reduce bacteria coverage (Ling et al. 2014). However, it has been reported that micro-patterned surfaces, with certain pattern sizes and under certain flowing conditions, might aggravate biofilm formation and, filamentous structures, also known as streamers, might form on such surfaces and act as precursors to matured biofilms (Valiei et al. 2012; Vucko et al. 2014; Hassanpourfard et al. 2016). Even though the body of research on micro-patterned surfaces has increased in recent years, there remains a need for studying the biofilm inhibitory effect of these surfaces when considering the operating conditions of the TSSHPS, which is a practical system already in use, e.g. the flowing conditions in the heat exchangers and the bacteria specific to the treated sewage.

For this work, micro-patterned surfaces with different pattern shapes and sizes were fabricated for biofilm inhibition. Model sewage was prepared and a rotating coupon device was used to simulate the operating conditions in the TSSHPS. Different testing methods were used to analyze the biofilms on the micro-patterned surfaces. Results at both macro- and micro-levels have been obtained to investigate the biofilm inhibitory effect and possible inhibitory mechanisms of the micro-patterned surfaces.

\section{Materials and methods}

\section{Micro-patterned surface processing}

The micro-patterned surfaces in the experiments were prepared using the wafer photolithography technology described by Lopez et al. (2010). Briefly, 4-inch N-type wafers (Topvendor Tech., Beijing, China), which were polished on both sides, $1 \mathrm{~mm}$ thick and with a Si purity of $99.9999 \%$, were cleaned with a mixture of sulfuric acid and hydrogen peroxide for $10 \mathrm{~min}$ and then washed in an ultrasonic cleaner for $30 \mathrm{~min}$. Then EPG-590, a positive photoresist, was spincoated on the wafers at a speed of 5,000 rpm for 30 seconds for a desired thickness. The photoresist-coated wafers were 
exposed through a photomask (Institution of Microelectronics of Chinese Academy of Sciences, Beijing, China), and the light-transmitting zones in the photomasks were designed with different shapes (stripe and cube) and sizes (1, 2, 5, 10, 20, 50, and100 $\mu \mathrm{m}$ ). The wafers were transferred to a high resolution mask aligner (ABM, Beijing, China) with an exposure time of 5 s. Finally the wafers were etched and immersed in photoresist developer to form micro-patterns, all with a height of $1 \mu \mathrm{m}$, as the diameter of the bacteria used in this study was close to $1 \mu \mathrm{m}$. Some of the accordingly developed micro-patterned surfaces were shown in Fig. 1.

Then the wafers were laser cut (Foxconn Nano Center, Beijing, China) into square coupons with the size of $20 \mathrm{~mm} \times 20$ $\mathrm{mm} \times 1 \mathrm{~mm}$ to fit the rotating coupon device. Prior to use, the coupons were washed in ultrafiltered water and then a mixture of ethanol and acetone, and ultrasonic cleaned at $50^{\circ} \mathrm{C}$ for $120 \mathrm{~min}$, to remove impurities such as micro silicon debris, unwanted bacteria, and chemical residuals on the surfaces.

\section{Bacteria culture and model sewage preparation}

A previous study by Tian et al. (2012a) has monitored the water quality of the treated sewage in six sewage plants in Beijing, and the results were used to determine the water quality parameters, e.g. temperature, inorganic ion concentrations, biological oxygen demand (BOD) and $\mathrm{pH}$, for model sewage preparation under laboratory conditions in this study.

Polymerase chain reaction and 16S rRNA analysis were performed on the treated sewage and the results showed that Bacillus sp. was the dominant bacteria in the treated sewage $(\geq 62 \%)$. B. subtilis was commonly found in soil and organic sewage and was identified in the sewage in Beijing (Tian et al. 2012a). Studies have shown that glucose, fructose, sucrose and protein were the main EPS components of B. subtilis and these components produced in biofilms were significantly more than those produced by bacteria in culture solutions (Harmawan and Ting 2016). In this study, B. subtilis was used for model sewage preparation and was kindly provided by the Biomedical Engineering Department in Tsinghua University. 
B. subtilis solution was mixed with $100 \%$ sterilized glycerol at a $1: 1$ ratio, then precooled in a $-20^{\circ} \mathrm{C}$ refrigerator, and stored in a $-80^{\circ} \mathrm{C}$ refrigerator. For each trial, the stored samples were first plate streaked on LB agars (Thermo Fisher, MA, USA), which were then incubated at $30^{\circ} \mathrm{C}$ for $24 \mathrm{~h}$. A single colony formed on the plates was picked and inoculated to the culture solution, which consisted of $1 \mathrm{wt} \%$ glucose, $1 \mathrm{wt} \%$ peptone, $0.5 \mathrm{wt} \%$ beef extract, and $0.5 \mathrm{wt} \% \mathrm{NaCl}$ (Sinopharm, Beijing, China). Prior to inoculation, the culture solution was autoclaved at $121^{\circ} \mathrm{C}$ for $30 \mathrm{~min}$. The inoculated culture solution was then incubated in a shaker at $30^{\circ} \mathrm{C}, 200 \mathrm{rpm}$ for $24 \mathrm{~h}$ to reach a final bacterial concentration of approximately $1.0 \times 10^{9} \mathrm{CFU} / \mathrm{ml}$.

Then the bacterium solution was diluted to ultra-filtered water to reach a concentration of $1 \times 10^{5} \mathrm{CFU} / \mathrm{ml}$, which was the average value of bacteria concentration of the treated sewage during summer operating conditions in the TSSHPS.

Solutions of glucose, sodium hydroxide and calcium chloride were added to the bacterium solution to adjust the BOD, $\mathrm{pH}$ and the concentration of $\mathrm{Ca}^{2+}$ to $15 \mathrm{mg} / \mathrm{l}, 7.2$ and $65 \mathrm{mg} / \mathrm{l}$, which were the average values of the treated sewage during summer operating conditions.

Thus, the model sewage with certain bacteria concentration and water quality parameters was prepared and then used for biofilm formation.

\section{The rotating coupon device and experimental procedure}

In this study, a rotating coupon device (Motian Tech., Suzhou, China) was used to form biofilms on the micro-patterned surfaces. The schematic diagram of the setup is shown in Fig. 2.

First, three wafer coupons with micro-patterned surfaces were fixed using screw nuts onto the rotating shaft. The angular velocity was set at $96 \mathrm{rpm}$, and the linear velocity at the micro-patterned surfaces was $0.4 \mathrm{~m} / \mathrm{s}$, which was a common flow velocity in plate heat exchangers. Then the prepared model sewage was contained in a polyethylene beaker and the coupons were immersed and rotated in the model sewage. The beaker was placed in the thermal controlled 
water bath of the rotating coupon device and the temperature was set at $25^{\circ} \mathrm{C}$, which was the average temperature of the treated sewage during summer operating conditions of the TSSHPS. A T thermal couple (Omega, Connecticut, USA) was placed in the beaker to monitor the temperature of the model sewage. The results showed that the temperature reached $25^{\circ} \mathrm{C}$ in less than $30 \mathrm{~min}$ after the beaker was placed in the water bath, and remained at $25 \pm 0.2^{\circ} \mathrm{C}$ during the whole process.

The biofilm-formation experiments lasted for 5 days. Initial trials by Yang et al. (2013), which lasted over 30 days, indicated that 5 days were sufficient for the biofilm growth to reach the stable phase.

In this study, as the model sewage was contained in a closed system, the nutrient would be consumed and the bacteria viability might decrease over time. So during the experiments, every $12 \mathrm{~h}$ fresh model sewage was prepared to replace the old model sewage in the beaker. LB agars were used to monitor the bacteria concentration in the beaker during the $12 \mathrm{~h}$ period (Alavi and Hansen 2013). Every $2 \mathrm{~h}$ since the beginning of the $12 \mathrm{~h}$ period, $1 \mathrm{ml}$ model sewage in the beaker was diluted and spread on the agars. The number of colonies was counted to calculate the bacteria concentration in the model sewage.

\section{Biofilm analysis}

\section{Biofilm wet weight}

As the biofilm thermal resistance, which is positively correlated with the wet weight of the biofilms (Tian et al. 2012a; Yang et al. 2013), is the main interest in this study, the biofilm weight wet was weighed every 24 h during the experiments. Prior to being weighed, the coupons were taken off from the shaft and suspended vertically in air for 5 min to drain off the water droplets of the biofilms. A previous study by Yang et al. (2015) showed that 5 min was long enough for all the extraneous water to be eliminated. The remaining water was stabilized water in the biofilms, and such static water led to thermal resistance increase in the heat exchangers and should not be eliminated. The coupons were then weighed using a 
XS105 balance (Mettler Toledo, Zurich, Switzerland) with a precision of $\pm 0.01 \mathrm{mg}$. The biofilm wet weight per unit area, $m_{\mathrm{f}}$, was defined as:

$$
m_{\mathrm{f}}=\frac{M_{\mathrm{f}}-M_{\mathrm{c}}}{S}
$$

where $M_{\mathrm{f}}$ is the weight of the coupon with biofilm (g), $M_{\mathrm{c}}$ is the weight of the clean coupon (g), $S$ is the base area of the coupon without the influence of the patterns $\left(\mathrm{m}^{2}\right)$ and $m_{\mathrm{f}}$ is the biofilm wet weight per unit area $\left(\mathrm{g} / \mathrm{m}^{2}\right)$.

\section{Scanning electron microscopy}

An SEM (FEI, Oregon, USA) was used to visualize the bacteria settlement and the biofilm structures. Prior to being visualized, the biofilms should be pretreated. Briefly, the $24 \mathrm{~h}, 72 \mathrm{~h}$ and $120 \mathrm{~h}$ biofilms on the coupon surfaces were rinsed in phosphate buffer solution (PBS) for $10 \mathrm{~min}$ to remove the loosely attached cells. Then the biofilms were fixed using $2.5 \%(\mathrm{w} / \mathrm{v})$ glutaraldehyde at $4^{\circ} \mathrm{C}$ for $2 \mathrm{~h}$. Samples were rinsed in PBS for three times, 5 min each time. Then the biofilms were dehydrated using ethanol solutions of $50 \%(\mathrm{v} / \mathrm{v}), 70 \%, 90 \%, 100 \%, 100 \%$ and $100 \%$ for $10 \mathrm{~min}$ each, followed by overnight drying in a freeze drier (Alpha1-2LDplus, CHRIST, Beijing, China). Dried samples were mounted to SEM stubs and coated with evaporated gold for $60 \mathrm{~s}$. A voltage of $15 \mathrm{kV}$ was used for SEM photography of these samples.

\section{Confocal laser scanning microscopy}

CLSM was used to assess the cell viability, 3D structure, biovolume and thickness of the biofilms. First, the $24 \mathrm{~h}, 72 \mathrm{~h}$ and $120 \mathrm{~h}$ biofilms were dyed with BacLight ${ }^{\circledR}$ bacterial viability kit (Invitrogen, California, USA) according to the manufacturer's instructions. The kit included two fluorescent nucleic acid stains, the red-fluorescent propidium iodide and the green-fluorescent SYTO ${ }^{\circledR}$ 9. Briefly, the two stains were mixed at a 1:1 ratio, and $6 \mu \mathrm{l}$ of the mixed stain was added to $1 \mathrm{ml}$ of deionized water. The biofilms on the coupons were then covered with $500 \mu \mathrm{l}$ of the solution and stained for $25 \mathrm{~min}$ in the dark, followed by washing with deionized water for $5 \mathrm{~min}$ to remove the stain residuals

The stained coupons were then put on the objective stage of a LSM-710 CLSM (Carl Zeiss, Oberkochen, Germany) and 
the biofilms were pictured with a $40 \times$ objective lens. Five random fields of view were imaged for each sample for quantitative analysis (biovolume and thickness). Each field covered a surface area of $212.3 \times 212.3 \mu \mathrm{m}^{2}$ and Z-stack images were obtained using the ZENS2010 software. Shooting parameters were set at: pinhole $46.7 \mu$ m; laser intensity 1.5\%; master gain 550 for PI and SYTO ${ }^{\circledR} 9$ and 8 bit image resolution with $1024 \times 1024$ image size.

The image stacks were imported to the software IMARIS (Bitplane, Zurich, Switzerland), and the "Smart 3D" function in the software was used for 3D reconstruction of the biofilm images. The "Surpass" function was used to show the biofilm thickness. The "Surfaces" function, a sub-function of the "Surpass" function, with a surfaces area detail level of $0.1 \mu \mathrm{m}$ was used to calculate the biovolume of the live and dead cells.

\section{Statistical analysis}

In this study, the results are reported as mean value \pm standard deviation, and analyzed with one-way analysis of variance (ANOVA). All statistical analyses were performed with MATLAB (version 8.3, Mathworks, MA, USA).

\section{Results}

\section{Bacteria concentration of the model sewage}

In this study, plate counting was used to monitor the bacteria concentration of the model sewage in every $12 \mathrm{~h}$ period, and the result was shown in Fig. 3. It could be seen that the bacteria concentration of the model sewage during the $12 \mathrm{~h}$ period was constant at $(1.0 \pm 0.2) \times 10^{5} \mathrm{CFU} / \mathrm{ml}$ and did not change significantly $(F=0.53, p=0.75)$.

\section{Biofilm wet weight}

During the experiments, the coupons were weighed every $24 \mathrm{~h}$. The biofilm wet weight development and the $120 \mathrm{~h}$ final biofilm wet weight on various surfaces were shown in Fig. 4.

As can be seen in Fig. 4, the biofilm wet weight on the control group surfaces (plain surfaces without any patterns) increased over time, reaching a final value of $350 \sim 450 \mathrm{~g} / \mathrm{m}^{2}$ at $120 \mathrm{~h}$. In addition, micro-patterned surfaces with small 
pattern sizes $(1 \mu \mathrm{m}$ and $2 \mu \mathrm{m})$ inhibited biofilm wet weight growth significantly when compared to the control group surfaces, while there was no significant biofilm wet weight decrease on other micro-patterned surfaces.

To get a further understanding of the influence of the pattern shape and size, the biofilm wet weight of the $120 \mathrm{~h}$ biofilms on various surfaces was shown in Fig. 4C and Fig. 4D. The results showed that, for the stripe surfaces, 1, 2 and 5 $\mu \mathrm{m}$ surfaces decreased biofilm wet weight significantly $(p<0.01)$, and for the cube surfaces, 1 and $2 \mu \mathrm{m}$ surfaces decreased biofilm wet weight significantly $(p<0.01)$. For both patterns, surfaces with pattern sizes larger than $10 \mu \mathrm{m}$ hardly showed any inhibitory effect $(p>0.05)$.

The statistics and the ANOVA results of the $120 \mathrm{~h}$ biofilm wet weight were shown in Table 1 . The results indicated that, for both patterns, $1 \mu \mathrm{m}$ and $2 \mu \mathrm{m}$ surfaces inhibited biofilm formation significantly $(p<0.01$ and $p<0.01)$, and the $5 \mu \mathrm{m}$ surfaces inhibited biofilm formation as well, but less significantly $(p<0.01$ and $p<0.05)$. Most surfaces with larger micropatterns showed no inhibitory effect $(p>0.05)$. For the two micro-pattern shapes, there was no significant difference between each other with $p$ in most groups larger than 0.05 .

\section{SEM imaging of the biofilms}

Bacteria attached to the surfaces and the structure of the biofilms developed over time. SEM was used to observe the topographies of the $24 \mathrm{~h}, 72 \mathrm{~h}$ and $120 \mathrm{~h}$ biofilms on various surfaces. Fig. 5 showed the SEM pictures of biofilms on $1 \mu$ m, $20 \mu \mathrm{m}$ micro-patterned surfaces and the control group surfaces. Topographies of the biofilms on other micro-patterned surfaces $(2,5,10,50,100 \mu \mathrm{m}$, data not shown) followed a similar trend noted in Fig. 5.

As can be seen in Fig. 5-A1 and B1, for the $24 \mathrm{~h}$ biofilms, single rod-shaped cells attached to the $1 \mu \mathrm{m}$ micro-patterned surfaces and thin layers of bacterial colony were formed. Besides, there were streamers on the $1 \mu$ m stripe surface, which was consistent with the study by Valiei et al. (2012). However, for the $24 \mathrm{~h}$ biofilms on the $20 \mu \mathrm{m}$ micro-patterned surfaces and control group surfaces, a large amount of bacteria settled and biofilms with three-dimensional structures 
were formed (Fig. 5-C1, Fig. 5-D1 and Fig. 5-E1)..

For the $72 \mathrm{~h}$ biofilms, more cells settled to the $1 \mu \mathrm{m}$ surfaces and more streamers were formed. These streamers created a web-like structures and thin layers of biofilm were formed (Fig. 5-A2 and Fig. 5-B2). On the $20 \mu \mathrm{m}$ and control group surfaces, large bulks of biofilm with three-dimensional porous structures were formed and covered the majority of the solid substrates (Fig. 5-C2, Fig. 5-D2 and Fig. 5-E2).

For the $120 \mathrm{~h}$ biofilms on the $1 \mu \mathrm{m}$ surfaces, thin EPS layers covered the whole substrates and formed several small protuberances (Fig. 5-A3 and Fig. 5-B3). On the $20 \mu \mathrm{m}$ and control group surfaces, matured biofilms with certain thickness covered the whole substrates and the original micro-patterns could not been seen anymore (Fig. 5-C3, Fig. 5-D3 and Fig. 5-E3).

\section{CLSM imaging of the biofilms and quantitative analysis}

$24 \mathrm{~h}, 72 \mathrm{~h}$ and $120 \mathrm{~h}$ biofilms were dyed with vital stains and imaged with a CLSM. The CLSM pictures of biofilms on 1 $\mu \mathrm{m}, 20 \mu \mathrm{m}$ and control group surfaces were shown in Fig. 6. As could be seen in Fig. 6, the structural development of biofilms on these surfaces was consistent with that indicated by the SEM pictures.

At $24 \mathrm{~h}$, on the $1 \mu \mathrm{m}$ surfaces, only several single cells attached to the surfaces. Furthermore, it could be seen that on these surfaces, most of the rod-shaped bacteria settled along the bottom of the micro-patterns and the outlines of the patterns could be seen (Fig. 6-A1 and Fig. 6-B1). On the $20 \mu \mathrm{m}$ and control group surfaces, clusters of bacteria and layers of biofilm were observed (Fig. 6-C1, Fig. 6-D1 and Fig. 6-E1).

At $72 \mathrm{~h}$, on the $1 \mu \mathrm{m}$ surfaces, both single cells and thin biofilms could be observed (Fig. 6-A2 and Fig. 6-B2). On the 20 $\mu \mathrm{m}$ and control group surfaces, the biofilms developed into a thick and porous structure (Fig. 6-C2, Fig. 6-D2 and Fig. 6-E2).

At $120 \mathrm{~h}$, on the $1 \mu \mathrm{m}$ surfaces, thin biofilms with filament EPS and small protuberances were formed (Fig. 6-A3 and Fig. 6-B3). On the $20 \mu \mathrm{m}$ and control group surfaces, matured biofilms developed into a dense structure (Fig. 6-C3, Fig. 6- 
D3 and Fig. 6-E3).

Furthermore, as can be seen in Fig. 6, the majority of the fluorescence is green and very little red fluorescence could be observed, suggesting the majority of the cells in the biofilms were live cells.

Imaris was used for quantitative analysis of the CLSM pictures. The calculated biovolume and thickness of the biofilms on various surfaces were shown in Fig. 7. It can be seen that the $1 \mu \mathrm{m}$ and $2 \mu \mathrm{m}$ surfaces inhibited biofilm formation, with both the biovolume and biofilm thickness significantly less than the control group $(p<0.01)$. However, surfaces with micro-pattern sizes larger than $5 \mu \mathrm{m}$ showed no significant inhibitory effect $(p>0.05)$, and the biovolume and biofilm thickness on some of these surfaces were significantly larger than those on the control group. When comparing the two patterns, it could be observed that there was no significant difference found between the biofilms on stripe surfaces and cube surfaces $(p>0.05)$. This is in line with the results of the biofilm wet weight.

\section{Discussion}

Numerous studies have been carried out to investigate the formation and inhibition of biofilms. In some of these studies, open circulation systems were used to provide biofilm-forming fluids with steady bacteria concentrations (Percival et al. 1999; Sanchez et al. 2013). However, more chose to place the substrates in closed systems, such as Petri dishes or 96-well plates (Martino et al 2003; Machado et al 2015; Brambilla et al 2016). As the biofilm-formation experiments in such studies did not last long (usually less than $48 \mathrm{~h}$ ), not many has considered the decline of bacteria concentration that might happen in such closed systems.

Studies have shown that bacteria concentration and nutrient level had significant influences on biofilm formation (Cerca et al. 2004). In this study, as the biofilm-formation experiments lasted for $120 \mathrm{~h}$ and the model sewage was contained in a closed system, the possible decline of bacteria concentration must be considered. The bacteria concentration of the model sewage was monitored, and the results showed that the bacteria concentration did not change significantly over time 
during the $12 \mathrm{~h}$ period experiments, so it could be considered that the model sewage had a stable biofilm-forming ability. The bacteria concentration not decreasing significantly over the $12 \mathrm{~h}$ period might be due to the fact that the bacteria solution was diluted and some original culture solution was added to the model sewage. Besides, glucose was added to the model sewage to adjust the BOD to $15 \mathrm{mg} / \mathrm{l}$, so with the low bacteria concentration and extra nutrient in the model sewage, the bacteria would not die during the $12 \mathrm{~h}$ period and the bacteria concentration could remain at a constant level.

In nature, the majority of bacteria exist in biofilms and live on surfaces or at interfaces (Branda et al. 2005). Bacteria in the liquids prefer to settle on surfaces and then secrete EPS to form biofilms. In this study, biofilms were formed on the coupon surfaces as the coupons were immersed and rotated in the model sewage. The biofilm wet weight on the control group surfaces increased over time and the final biofilm wet weight at $120 \mathrm{~h}$ was consistent with the stable biofilm wet weight in the 30-day trials (Yang et al. 2013).

From the results of biofilm wet weight development described in Fig. 4, it is evident that surfaces with small pattern sizes inhibited biofilm formation. Similar trends have been observed in previous studies (Vucko et al. 2014). Micropatterned PDMS surfaces with different pattern sizes have been developed and immersed in seawater and solutions containing a wide range of marine biofilm-forming organisms. It was found that the settlement was inhibited on surfaces with pattern sizes close to the sizes of the organisms. The author explained it with the attachment point theory, i.e. surfaces with pattern size close to the size of the bacterium provide less attachment points than surfaces with large or small pattern size. Fig. 8 is a schematic diagram illustrating the attachment point theory. When the attachment points are decreased, the substrate and the bacteria become less connected and the settlement is considered more unstable.

In this study, surfaces with pattern size ranging from 1 to $100 \mu \mathrm{m}$ were designed to testify the attachment point theory. The results showed that, $B$. subtilis, a rod-shaped bacterium with $1 \mu \mathrm{m}$ in diameter and $3 \mu \mathrm{m}$ in length, settled significantly less on the $1 \mu \mathrm{m}$ and $2 \mu \mathrm{m}$ surfaces, and surfaces with pattern sizes larger than $5 \mu \mathrm{m}$ barely showed any inhibition. So this 
result could be explained with the attachment theory, i.e. the inhibition of bacteria settlement and subsequent biofilm formation was due to that $1 \mu \mathrm{m}$ and $2 \mu \mathrm{m}$ surfaces provided less attachment points and the bacteria was less steadily settled on these surfaces.

However, in addition to attachment point theory, other researchers have explained the biofilm inhibitory effect of micropatterned surfaces with the change of wettability, surface free energy, or thermaldynamical state (Kananeh et al. 2010; Decker et al. 2013; Vasudevan et al. 2014). Most of these experiments were carried out under static immersion conditions. Some has considered the influence of flowing conditions (Halder et al. 2014), and the results showed that the velocity fields and shear rate fields on the patterned surfaces were more non-uniform and the bacteria settlement was disturbed. It has been reported that the shear stress on surfaces with smaller microstructures varied more rapidly (Zussman et al. 2002). In this study, the results showed that surfaces with small pattern sizes inhibited biofilm formation significantly. As the experiments were performed under flowing conditions, it is possible that the flow field was more disrupted on the surfaces with small patterns, thus inhibiting the bacteria settlement. So the flow field disturbance is a potential explanation for the inhibition of biofilm formation of these surfaces. Further study is being carried out using CFD simulations to understand how the flow field changed on such surfaces and will be presented in the near future.

Bacteria settlement is the initial step of biofilm formation, and many previous studies have proposed that the biofilm mitigation could be attributed to the bacteria settlement inhibition (Vucko et al 2014; Moreira et al. 2015). With less bacteria cells attached to the surfaces, the subsequent cell reproduction and EPS secretion would be reduced and the biofilm formation would be inhibited. A similar phenomenon was observed in this study. It could be seen in Fig. 5 that at $24 \mathrm{~h}$, surfaces with small micro-patterns inhibited bacteria settlement significantly, so for the $120 \mathrm{~h}$ biofilms, when matured and dense biofilms were formed on the control group surfaces, only thin layers of biofilms were observed on the $1 \mu \mathrm{m}$ surfaces. The inhibition of the initial bacteria settlement on the $1 \mu \mathrm{m}$ and $2 \mu \mathrm{m}$ surfaces might be due to the fact that 
these surfaces, whose pattern sizes were close to the bacterium, provided less attachment points (as illustrated in Fig. 8). As the experiments were performed under flowing conditions, these less steadily settled bacteria might be swept away from the surfaces.

However, it has been reported that the micro-patterned surfaces might lose the biofilm inhibitory effect after being immersed in seawater for a long period of time, mainly due to the fact that the surfaces were totally covered by biofilms (Ling et al. 2014). The micro-patterned surfaces used in this study might have the same problem, so further studies with long-period experiments are needed to investigate the biofilm inhibitory effect of the surfaces after being totally covered.

In this study, CLSM was used to investigate the structural development and bacteria viability in the biofilms. The results suggested that the bacteria preferred to settle to the gaps instead of the top of the micro-patterns (Fig. 6-A1 and Fig. 6B1). Studies explained this with the relatively static flowing conditions in the recessed regions (Hou et al. 2011).

In addition, the results suggested that, in the biofilms formed on the micro-patterned surfaces, the majority of the cells were viable (Fig. 6-A to Fig. 6-D). In previous studies (Sapkota et al. 2011; Al-Fori et al. 2014), surfaces with zinc oxide ( $\mathrm{ZnO})$ nanorods have been developed to inhibit biofilm formation, and it was found that the mortality of the settled organisms increased significantly and the biofilm inhibition was mainly due to the bactericidal effect of the ZnO nanorods. In this study, however, the micro-patterned surfaces did not kill the bacteria, so the biofilm inhibition was most likely due to certain physical processes, as described by the attachment point theory and the flow field disturbance, instead of any bactericidal effect.

Furthermore, it was interesting to notice that in Fig. 7A, for most surfaces, the biovolume decreased at $120 \mathrm{~h}$, which did not match the biofilm wet weight development. This might be caused by the block of the fluorescent signal The matured $120 \mathrm{~h}$ biofilms have developed into a certain thickness, and the fluorescent signals of the cells in the bottom of the biofilms were blocked by the bacteria cells, the EPS and the water in the top layer. Thus the bottom signals were very weak and 
could not be received by the CLSM, and the accordingly calculated biovolume would be smaller than the true value. In addition to that, this difference in biofilm wet weight and biovolume might be caused by the formation of spores as well. $B$. subtilis, a spore forming organism, could become spores in low nutrient or high metabolite conditions (Setlow et al. 2008). In this study, the bacteria in the bottom of the $120 \mathrm{~h}$ biofilms might become spores due to the lack of nutrient and the abundance of accumulated metabolite. Such spores would not be dyed by the fluorescent stains, thus no signal could be received by the CLSM. So the accordingly calculated biovolume might decrease when compared to that of the $72 \mathrm{~h}$ biofilms. Besides, using the thickness $(\mu \mathrm{m})$ shown in Fig. 7B and biofilm density $\left(\mathrm{kg} / \mathrm{m}^{3}\right)$ to roughly estimate the biofilm wet weight, the estimated value would be significantly lower than the measured value shown in Fig. 4 . This is mainly due to that the biofilms were compressed between the coupon and a supporting cover slip as the CLSM worked in an inverted mode. So the biofilm thickness might decrease as the biofilms were compressed and the accordingly estimated biofilm wet weight would be less than the measured value.

In conclusion, from the results described in this study, surfaces with small pattern sizes (1 $\mu \mathrm{m}$ and $2 \mu \mathrm{m})$ inhibited biofilm formation significantly and the inhibitory effect showed no significant difference between the two pattern shapes. However, further studies are needed to understand the exact mechanism for biofilm inhibition of these surfaces and to investigate the biofilm inhibitory effect in long-period experiments.

\section{Acknowledgments}

This work was supported by The National Natural Science Foundation of China (grant no. 51476090 and grant no. 50976060) and The Science Fund for Creative Research Group (grant no. 51321002).

\section{References}

Alavi, H.E.D., and Hansen, L.T. 2013. Kinetics of biofilm formation and desiccation survival of Listeria monocytogenes in single and dual species biofilms with Pseudomonas fluorescens, Serratia proteamaculans or Shewanella baltica on food- 
grade stainless steel surfaces. Biofouling, 29(10): 1253-1268. doi: 10.1080/08927014.2013.835805.

Al-Fori, M., Dobretsov, S., Myint, M.T.Z., and Dutta, J. 2014. Antifouling properties of zinc oxide nanorod coatings. Biofouling, 30(7): 871-882. doi: 10.1080/08927014.2014.942297.

Baier, R.E. 2006. Surface behaviour of biomaterials: the theta surface for biocom-patibility. J. Mater. Sci.: Mater. Med. 17(11): 1057-1062. doi: 10.1007/s10856-006-0444-8.

Brambilla, E., Ionescu, A.C., Cazzaniga, G., Ottobelli, M., and Samaranayake, L.P. 2016. Levorotatory carbohydrates and xylitol subdue Streptococcus mutans and Candida albicans adhesion and biofilm formation. J. Basic Microbiol 56: 480-492. doi: $10.1002 /$ jobm.201500329.

Branda, S.S., Vik, A., Friedman, L., and Kolter, R. 2005. Biofilms: the matrix revisited. Trends Microbiol. 13(1): 20-26. doi: 10.1016/j.tim.2004.11.006.

Callow, M.E., Callow, J.A., Ista, L.K., Coleman, S.E., Nolascon, A.C., and López, G.P. 2000. Use of self-assembled monolayers of different wettabilities to study surface selection and primary adhesion processes of green algal (Enteromorpha) zoospores. Appl. Environ. Microbiol. 66(8): 3249-3254. doi: 10.1128/AEM.66.8.3249-3254.2000.

Cartwright, D.K., and Spurr, H.W. 1998. Biological control of Phytophthora parasitica var. nicotianae on tabacco seedlings with non-pathogenic binucleate Rhizoctonia fungi. Soil. Biol. Biochem. 30(14): 1879-1884. doi: 10.1016/S00380717(98)00019-4.

Cerca, N., Pier, G.B., Vilanova, M., Oliveira, R., and Azeredo, J. 2004. Influence of batch or fedbatch growth on Staphylococcus epidermidis biofilm formation. Lett. Appl. Microbiol. 39(5): 420-424. doi: 10.1111/j.1472765X.2004.01601.X.

Chan, Y.J., Chong, M.F., Law, C.L., and Hassell, D.G. 2009. A review on anaerobic-aerobic treatment of industrial and municipal wastewater. Chem. Eng. J. 155(1): 1-18. doi:10.1016/j.cej.2009.06.041. 
Chug, R., Gour, V. S., Mathur, S., and Kothari, S. L. 2016. Optimization of Extracellular Polymeric Substances production using Azotobacter beijreinckii and Bacillus subtilis and its application in chromium (VI) removal. Bioresour. Technol. 214: 604-608. doi: 10.1016/j.biortech.2016.05.010

Dahlström, M., Jonsson, H., Jonsson, P.R., and Elwing, H. 2004. Surface wettability as a determinant in the settlement of the barnacle Balanus improvisus (DARWIN). J. Exp. Mar. Bio. Ecol. 305(2): 223-232. doi: 10.1016/j.jembe.2003.12.013.

Decker, J.T., Kirschner, C.M., Long, C.J., Finlay, J.A., Callow, M.E., Callow, J.A., et al. 2013. Engineered antifouling microtopographies: an energetic model that predicts cell attachment. Langmuir, 29(42): 13023-13030. doi: 10.1021/la402952u.

Dolan, R.M., and Costerton, J.W. 2002. Biofilms: survival mechanisms of clinically relevant microorganisms. Clin. Microbiol. Rev. 15(2): 167-193. doi: 10.1128/CMR.15.2.167-193.200.

Galván, E. M., Mateyca, C., and Ielpi, L. 2016. Role of interspecies interactions in dual-species biofilms developed in vitro by uropathogens isolated from polymicrobial urinary catheter-associated bacteriuria. Biofouling, 32(9):1067-1077. doi: 10.1080/08927014.2016.1231300.

Haggag, W. M. and Timmusk, S. 2008. Colonization of peanut roots by biofilm-forming Paenibacillus polymyxa initiates biocontrol against crown rot disease. J. Appl Microbiol. 104: 961-969. doi: 10.1111/j.1365-2672.2007.03611.x.

Halder, P., Nasabi, M., Jayasuriya, N., Shimeta, J., Deighton, M., Bhattacharya, S., et al. 2014. An assessment of the dynamic stability of microorganisms on patterned surfaces in relation to biofouling control. Biofouling, 30(6): 695-707. doi: $10.1080 / 08927014.2014 .914177$.

Harmawan, A. and Ting, Y. 2016. Investigation of extracellular polymeric substances (EPS) properties of $P$. aeruginosa and B. subtilis and their role in bacterial adhesion. Colloids Surf. B. Biointerfaces, 146: 459-468. doi: 10.1016/j.colsurfb. 2016.06.039. 
Hassanpourfard, M., Ghosh, R., Thundat, T., and Kumar, A. 2016. Dynamics of bacterial streamers induced clogging in microfluidic devices. Lab Chip, 16: 4091-4096. doi: 10.1039/c6lc01055e.

Hou, S., Gu, H., Smith, C., and Ren, D. 2011. Microtopographic patterns affect Escherichia coli biofilm formation on poly(dimethylsiloxane) surfaces. Langmuir, 27(6): 2686-2691. doi: 10.1021/la1046194.

Joshi, R.G., Goel, A., Mannari, V., Finlay, J.A., Callow, M.E., and Callow. J.A. 2009. Evaluating fouling-resistance and foulingrelease performance of smart polyurethane surfaces: an outlook for efficient and environmentally benign marine coatings. J. Appl. Polym. Sci. 114(6): 3693-3703. doi: 10.1002/app.30899.

Kananeh, A.B., Scharnheck, E., Kück, U.D., and Räbiger, N. 2010. Reduction of milk fouling inside gasketed plate heat exchanger using nano-coatings. Food Bioprod. Process. 88(4): 349-356. doi: 10.1016/j.fbp.2010.09.010.

Ling, G.C., Low, M.H., Erken, M., Longford, S., Nielson, S., Poole, A.J., et al. 2014. Micro-fabricated polydimethyl siloxane (PDMS) surfaces regulate the development of marine microbial biofilm communities. Biofouling, 30(3): 323-335. doi: $10.1080 / 08927014.2013 .872778$.

Lopez, F.J.T., Rosengarten, G., Westein, E., Khoshmanesh, K., Jackson, S.P., Mitchell, A., et al. 2010. A microfluidics device to monitor platelet aggregation dynamics in response to strain rate micro-gradients in flowing blood. Lab. Chip, 10(3): 291302. doi: 10.1039/b916757a.

Machado, D., Palmeira-de-Oliveira, A., and Cerca, N. 2015. Optimization of culture conditions for Gardnerella vaginalis biofilm formation. J. Microbiol. Methods, 118: 143-146. doi: 10.1016/j.mimet.2015.09.007.

Mah, T.F., and O’Toole, G.A. 2001. Mechanisms of biofilm resistance to antimicrobial agents. Trends Microbiol. 9(1): 3439. doi: 10.1016/S0966-842X(00)01913-2.

Martino, P.D., Fursy, R., Bret, L., Sundararaju, B., and Phillips, R.S. 2003. Indole can act as an extracellular signal to regulate biofilm formation of Escherichia coli and other indole-producing bacteria. Can. J. Microbiol. 49(7): 443-449. doi: 
doi: $10.1139 /$ w03-056.

Meggers, F., and Leibundgut, H. 2011. The potential of wastewater heat and exergy: decentralized high-temperature recovery with a heat pump. Energy Build. 43(4): 879-886. doi:10.1016/j.enbuild.2010.12.008.

Moreira, J.M.R., Gomes, L.C., Simoes, M., Melo, L.F., and Mergulhão, F. 2015. The impact of material properties, nutrient load and shear stress on biofouling in food industries. Food Bioprod. Process. 95: 228-236. doi: 10.1016/j.fbp.2015.05.011.

Murthy, P.S., Venkatesan, R., Nair, K.V.K., and Ravindran, M. 2004. Biofilm control for plate heat exchangers using seawater from the open ocean for the OTEC power plant. Int. Biodeterior. Biodegr. 53(2): 133-140. doi: 10.1016/j.ibiod.2003.11.003.

Percival, S.L., Knapp, J.S., Wales, D.S., and Edyvean, R.G.J. 1999. The effect of turbulent flow and surface roughness on biofilm formation in drinking water. J. Ind Microbiol. Biot. 22(3): 152-159. doi: 10.1038/sj.jim.2900622.

Sanchez, Z., Tani, A., Suzuki, N., Kariyama, R., Kumon, H., and Kimbara, K. 2013. Assessment of change in biofilm architecture by nutrient concentration using a multichannel microdevice flow system. J. Biosci. Bioeng. 115(3): 326-331. doi: 10.1016/j.jbiosc.2012.09.018.

Sapkota, A., Anceno, A.J., Baruah, S., and Shipin, O.V. 2011. Zinc oxide nanorod mediated visible light photoinactivation of model microbes in water. Nanotechnology, 22(21): 1-7. doi: 10.1088/0957-4484/22/21/215703.

Scardino, A.J., and de Nys, R. 2011. Mini review: biomimetic models and bioinspired surfaces for fouling control. Biofouling, 27(1): 73-86. doi: 10.1080/08927014.2010.536837.

Setlow, B., Wahome, P. G., and Setlow, P. 2008. Release of small molecules during germination of spores of Bacillus species. J. Bacteriol. 2008, 190(13): 4759-4763. doi: 10.1128/JB.00399-08.

Steinhagen, R., Müller-steinhagen, H., and Maani, K. 1993. Problems and costs due to heat exchanger fouling in New Zealand industries. Heat Transf. Eng. 14(1): 19-30. doi: 10.1080/01457639308939791. 
Stoodley, P., Wilson, S., Hall-Stoodley, L., Boyle, J.D., Lappin-Scott, H.M., and Costerton, J.W. 2001. Growth and detachment of cell clusters from mature mixed-species biofilms. Appl. Environ. Microbiol. 67(12): 5608-5613. doi: 10.1128/AEM.67.12.5608-5613.2001.

Tian, L., Chen, X.D., Yang, Q.P., Chen, J.C., Shi, L., and Li, Q. 2012a. Effect of calcium ions on the evolution of biofouling by Bacillus subtilis in plate heat exchangers simulating the heat pump system used with treated sewage in the 2008 Olympic Village. Colloids Surf. B. Biointerfaces, 94(1): 309-316. doi: 10.1016/j.colsurfb.2012.02.015.

Tian, L., Chen, X.D., Yang, Q.P., Chen, J.C., Li, Q., and Shi, L. 2012b. Effect of silica dioxide particles on the evolution of biofouling by Bacillus subtilis in plate heat exchangers relevant to a heat pump system used with treated sewage. Chem. Eng. J. 188(16): 47-56. doi:10.1016/j.cej.2012.02.004.

Valiei, A., Kumar, A., Mukherjee, P.P., Liu, Y., Thundat, T. 2012. A web of streamers: biofilm formation in a porous microfluidic device. Lab Chip, 12: 5133-5137. doi: 10.1039/c2lc40815e.

Vasudevan, R., Kennedy, A.J., Merritt, M., Crocker, F.H., and Baney, R.H. 2014. Microscale patterned surfaces reduce bacterial fouling-microscopic and theoretical analysis. Colloids Surf. B. Biointerfaces, 117(1): 225-232. doi: 10.1016/j.colsurfb.2014.02.037.

Vejborg, R.M., and Klemm, P. 2008. Blocking of bacterial biofilm formation by a fish protein coating. Appl. Environ. Microbiol. 74(11): 3551-3558. doi: 10.1128/AEM.00279-08.

Vinh, D.C., and Embil, J.M. 2005. Device-related infections: a review. J. Long-Term Eff. Med. Implants, 15(5): 467-488. doi: 10.1615/JLongTermEffMedImplants.v15.i5.20.

Vucko, M.J., Poole, A.J., Carl, C., Sexton, B.A., Glenn, F.L., Whalan, S., et al 2014. Using textured PDMS to prevent settlement and enhance release of marine fouling organisms. Biofouling, 30(1): 1-16. doi: 10.1080/08927014.2013.836507.

Yang, Q.P., Wilson, D.I., Chen, X.D., and Shi, L. 2013. Experimental investigation of interactions between the temperature 
field and biofouling in a synthetic treated sewage stream. Biofouling, 29(5): 513-523. doi: $10.1080 / 08927014.2013 .790014$.

Yang, Q.P., Chang, S.Y., and Shi, L. 2015. Study on interactions between suspended matter and biofouling formed by treated sewage. Environ. Technol. 36(21): 2778-2785. doi: 10.1080/09593330.2015.1049211.

Zussman, E., Yarin, A.L., and Weihs, D. 2002. A micro-aerodynamic decelerator based on permeable surfaces of nanofiber mats. Exp. Fluids, 33(2): 315-320. doi: 10.1007/s00348-002-0435-6. 


\section{Tables}

Table 1. The $120 \mathrm{~h}$ biofilm wet weight $\left(\mathrm{g} / \mathrm{m}^{2}\right)$ on various surfaces and the ANOVA results

\begin{tabular}{|c|c|c|c|c|c|c|c|c|}
\hline & $1 \mu \mathrm{m}$ & $2 \mu \mathrm{m}$ & $5 \mu \mathrm{m}$ & $10 \mu \mathrm{m}$ & $20 \mu \mathrm{m}$ & $50 \mu \mathrm{m}$ & $100 \mu \mathrm{m}$ & control group \\
\hline Stripe & $227.3 \pm 17.7$ & $252.5 \pm 23.2$ & $269.9 \pm 21.8$ & $403.8 \pm 6.2$ & $356.8 \pm 11.2$ & $333.9 \pm 16.5$ & $359.3 \pm 25.0$ & $392.1 \pm 23.4$ \\
\hline surfaces & $* *$ & $* *$ & $* *$ & - & - & $*$ & - & \\
\hline Cube & $214.3 \pm 20.3$ & $272.9 \pm 19.0$ & $329.4 \pm 15.2$ & $342.8 \pm 10.5$ & $425.3 \pm 25.5$ & $322.7 \pm 23.4$ & $382.5 \pm 19.8$ & $372.1 \pm 14.8$ \\
\hline surfaces & $* *$ & $* *$ & $*$ & - & - & - & - & \\
\hline \multicolumn{9}{|l|}{ Pattern } \\
\hline difference & - & - & * Stripe & ** Cube & * Stripe & - & - & - \\
\hline
\end{tabular}

Note: The $120 \mathrm{~h}$ biofilm wet weight was shown in a way of mean value \pm standard deviation, and one-way ANOVA was performed to analyze the significant difference. The $1^{\text {st }}$ line showed the sizes of the patterns. The $2^{\text {nd }}$ and $3^{\text {rd }}$ lines showed the mean value and standard deviation of the final biofilm wet weight and the significant difference when compared to the control groups, on stripe and cube surfaces respectively. The $4^{\text {th }}$ line showed the significant difference between the biofilm wet weight on surfaces with the same pattern size but different pattern shapes, and which exhibited a stronger inhibitory effect. $\left(-, p \geq 0.05 ;^{*}, p<0.05 ;{ }^{* *}, p<0.01 . n=3\right)$. 


\section{Figure captions}

Figure 1. SEM pictures illustrating the topographies of the micro-patterned surfaces. The micro-patterns were fabricated on 4-inch wafers using the photolithography technology. Scale bar (on the right lower corner of each figure) $=100 \mu \mathrm{m}$, the heights of all patterns were $1 \mu \mathrm{m}$. Pattern size: A and D, $5 \mu \mathrm{m}$; B and E, $20 \mu \mathrm{m}$; C and F, $100 \mu \mathrm{m}$. Pattern shape: A-C, stripe; D-F: cube.

Figure 2. Schematic diagram of the rotating coupon device, which was used to simulate the biofilm formation process in the TSSHPS (A. Front view, B. Top view). The model sewage was contained in a beaker, which was placed in the water bath to maintain the temperature of the model sewage at $25^{\circ} \mathrm{C}$. The coupons were fixed onto the shaft and rotated in the model sewage at $96 \mathrm{r} / \mathrm{min}$.

Figure 3. Bacteria concentration in the model sewage during the $12 \mathrm{~h}$ periods. The results were shown in a way of mean value \pm standard deviation $(n=10)$. Even though the model sewage was contained in a closed system, the bacteria concentration did not change significantly during the $12 \mathrm{~h}$ periods $(F=0.53, p=0.75)$.

Figure 4. The biofilm wet weight development during the $120 \mathrm{~h}$ biofilm formation process and the final (120 h) biofilm wet weight. The results were shown in a way of mean value \pm standard deviation $(n=3)$. (A) Biofilm wet weight development on stripe pattern surfaces. (B) Biofilm wet weight development on cube pattern surfaces. (C) $120 \mathrm{~h}$ biofilm wet weight on stripe pattern surfaces. (D) $120 \mathrm{~h}$ biofilm wet weight on cube pattern surfaces. The results indicated that the $1 \mu \mathrm{m}$ and $2 \mu \mathrm{m}$ surfaces inhibited biofilm growth significantly, and surfaces with pattern sizes larger than $10 \mu \mathrm{m}$ showed no significant inhibitory effect. For the two micro-pattern shapes, there was no significant difference between each other.

Figure 5. SEM pictures illustrating the micro-structures of the biofilms. A1-A3, $24 \mathrm{~h}, 72 \mathrm{~h}$ and $120 \mathrm{~h}$ biofilms on $1 \mu \mathrm{m}$ stripe surfaces; B1-B3, $24 \mathrm{~h}, 72 \mathrm{~h}$ and $120 \mathrm{~h}$ biofilms on $1 \mu \mathrm{m}$ cube surfaces; C1-C3, $24 \mathrm{~h}, 72 \mathrm{~h}$ and $120 \mathrm{~h}$ biofilms on 20 
$\mu \mathrm{m}$ stripe surfaces; D1-D3, $24 \mathrm{~h}, 72 \mathrm{~h}$ and $120 \mathrm{~h}$ biofilms on $20 \mu \mathrm{m}$ cube surfaces; E1-E3, $24 \mathrm{~h}, 72 \mathrm{~h}$ and $120 \mathrm{~h}$ biofilms on control group surfaces. At 24 h, 72 h and 120 h, thicker and more inhomogeneous biofilms were observed on the $20 \mu \mathrm{m}$ and control group surfaces, compared to the biofilms on the $1 \mu \mathrm{m}$ surfaces. The $1 \mu \mathrm{m}$ surfaces significantly inhibited bacteria settlement and the subsequent biofilm formation. Scale bar (on the right lower corner of each figure) $=100 \mu \mathrm{m}$.

Figure 6. CLSM pictures illustrating the micro-structures and the cell viability of the biofilms. A1-A3, $24 \mathrm{~h}, 72 \mathrm{~h}$ and $120 \mathrm{~h}$ biofilms on $1 \mu \mathrm{m}$ stripe surfaces; B1-B3, $24 \mathrm{~h}, 72 \mathrm{~h}$ and $120 \mathrm{~h}$ biofilms on $1 \mu \mathrm{m}$ cube surfaces; C1-C3, 24 h, 72 h and $120 \mathrm{~h}$ biofilms on $20 \mu \mathrm{m}$ stripe surfaces; D1-D3, $24 \mathrm{~h}, 72 \mathrm{~h}$ and $120 \mathrm{~h}$ biofilms on $20 \mu \mathrm{m}$ cube surfaces; E1-E3, 24 h, $72 \mathrm{~h}$ and $120 \mathrm{~h}$ biofilms on control group surfaces. Green fluorescence indicated live bacteria cells. Red fluorescence, though could hardly be observed, indicated dead bacteria cells. The structural development of the biofilms showed a similar trend illustrated in Fig. 5. Most of the bacteria cells settled to the bottom of the patterns and the outline of the patterns could be seen in A1, A2, B1 and B2. The majority of cells were live cells (green fluorescence), indicating the micro-patterned surfaces showed no bactericidal effect. Scale bar (on the right lower corner of A1) = $100 \mu \mathrm{m}$.

Figure 7. Quantitative analysis of the $24 \mathrm{~h}, 72 \mathrm{~h}$ and $120 \mathrm{~h}$ biofilm CLSM pictures. (A) Biovolume (B) Biofilm thickness. The results were shown in a way of mean value \pm standard deviation $(n=5)$. The biovolume and biofilm thickness on $1 \mu \mathrm{m}$ and $2 \mu \mathrm{m}$ surfaces were significantly decreased. For the two pattern shapes, there was no significant difference between each other.

Figure 8. Schematic diagram illustrating the attachment point theory. A, surfaces with pattern size much smaller than the bacterium size. B, surfaces with pattern size close the bacterium size. $C$, surfaces with pattern size much larger than the bacterium size. Dark gray, the settled bacterium. Light gray, the substrate with micro-patterns. It could be seen that surface B provides only two attachment points, while surface A and C provide attachment zones. So the bacteria settlement on surface B is considered less stable. 
A

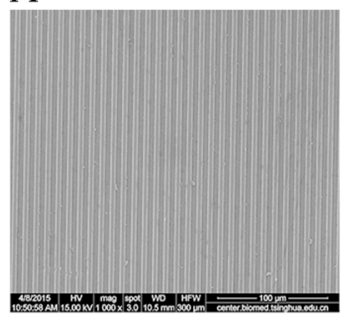

$\mathrm{D}$

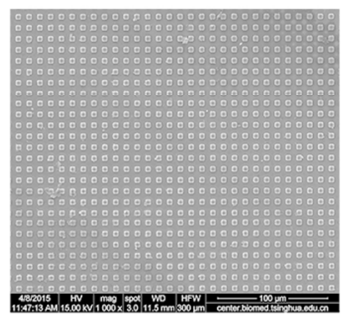

$\mathrm{B}$

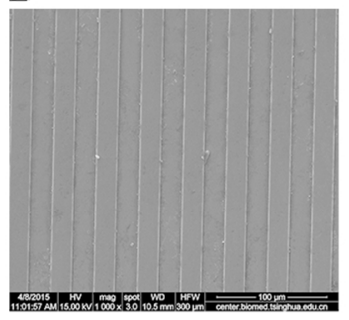

$\mathrm{E}$

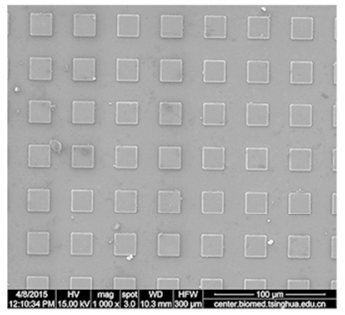

$\mathrm{C}$

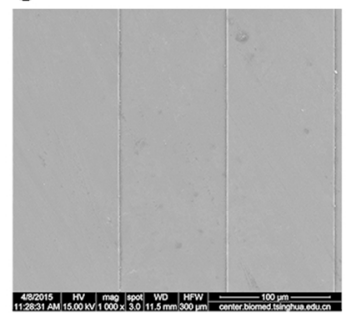

$\mathrm{F}$

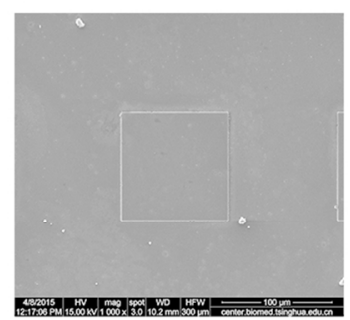

Figure 1. SEM pictures illustrating the topographies of the micro-patterned surfaces. The micro-patterns were fabricated on 4-inch wafers using the photolithography technology. Scale bar (on the right lower corner of each figure) $=100 \mu \mathrm{m}$, the heights of all patterns were $1 \mu \mathrm{m}$. Pattern size: $A$ and $D, 5 \mu \mathrm{m} ; B$ and $E, 20$ $\mu \mathrm{m}$; C and F, $100 \mu \mathrm{m}$. Pattern shape: A-C, stripe; D-F: cube.

$167 \times 94 \mathrm{~mm}(200 \times 200 \mathrm{DPI})$ 

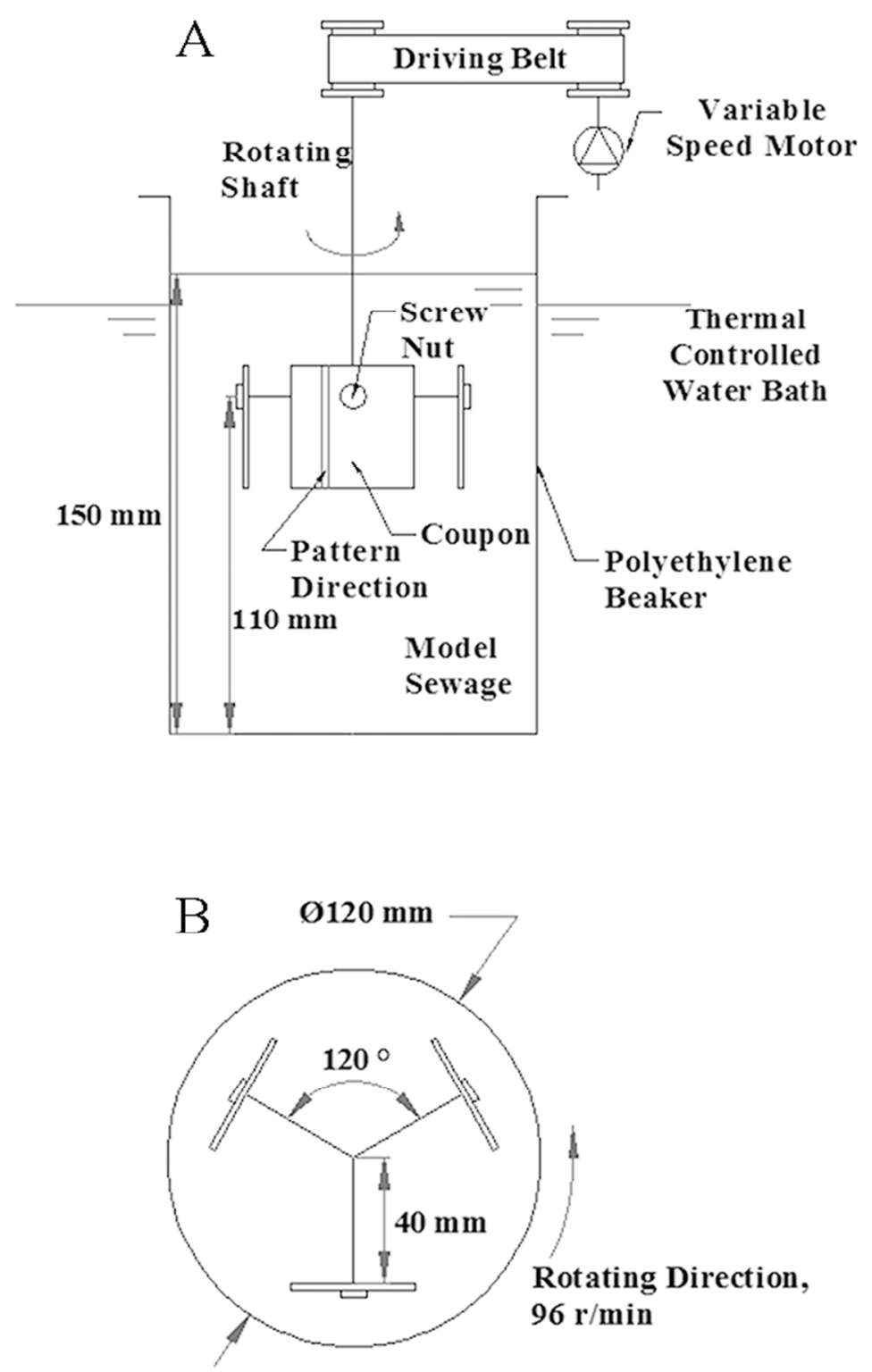

Figure 2. Schematic diagram of the rotating coupon device, which was used to simulate the biofilm formation process in the TSSHPS (A. Front view, B. Top view). The model sewage was contained in a beaker, which was placed in the water bath to maintain the temperature of the model sewage at $25^{\circ} \mathrm{C}$. The coupons were fixed onto the shaft and rotated in the model sewage at $96 \mathrm{r} / \mathrm{min}$.

$80 \times 129 \mathrm{~mm}(200 \times 200$ DPI $)$ 


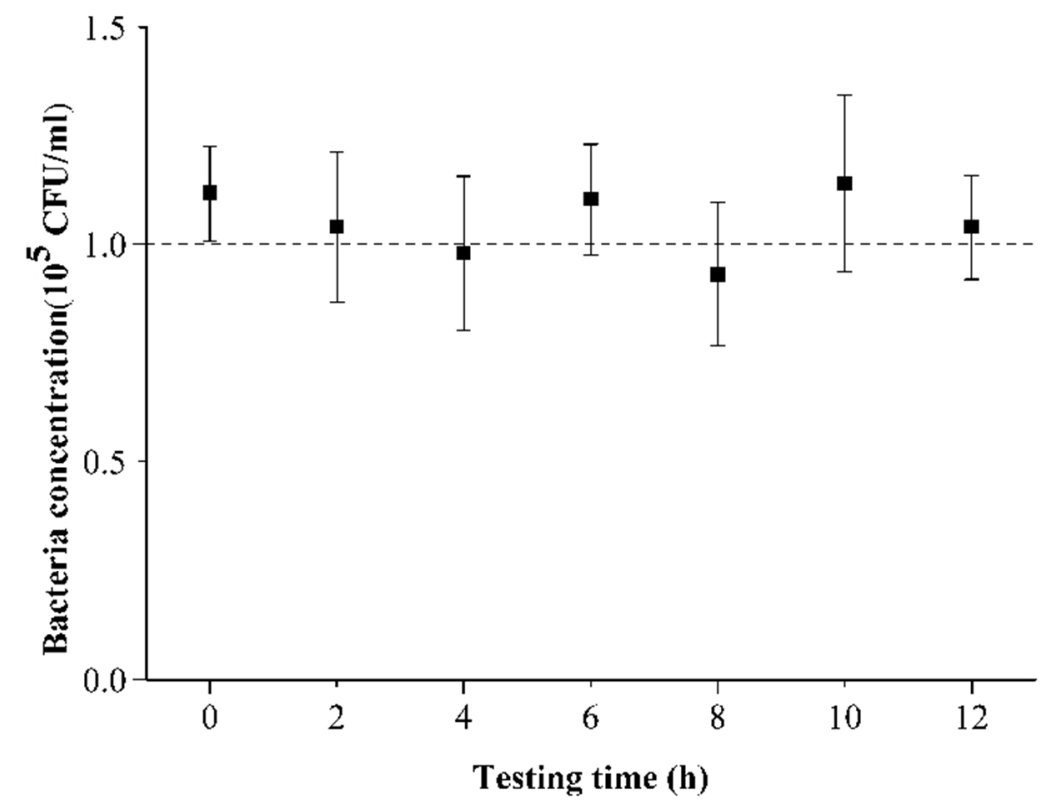

Figure 3. Bacteria concentration in the model sewage during the $12 \mathrm{~h}$ periods. The results were shown in a way of mean value \pm standard deviation $(n=10)$. Even though the model sewage was contained in a closed system, the bacteria concentration did not change significantly during the $12 \mathrm{~h}$ periods $(F=0.53, p=0.75)$.

$80 \times 55 \mathrm{~mm}(300 \times 300$ DPI $)$ 

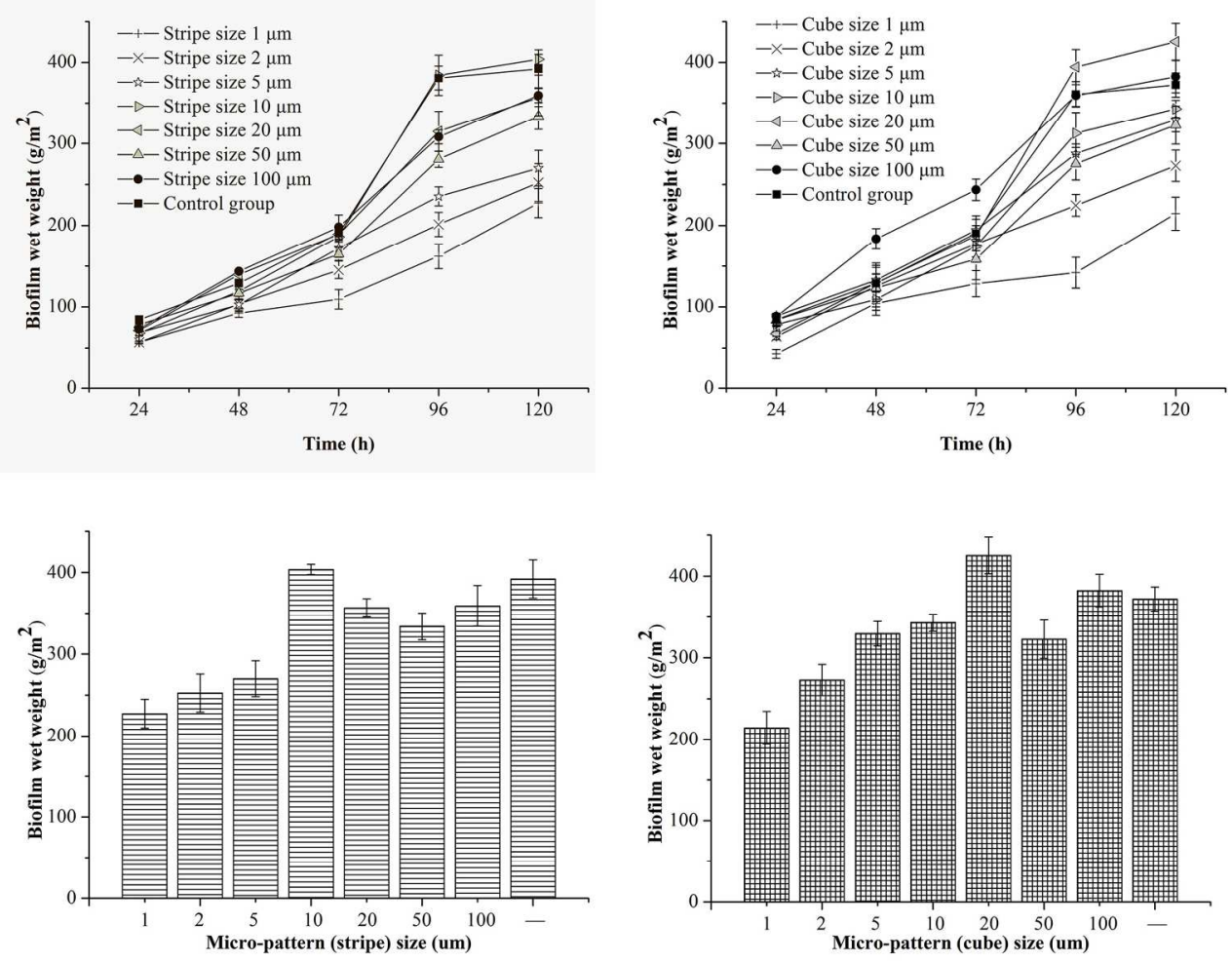

Figure 4. The biofilm wet weight development during the $120 \mathrm{~h}$ biofilm formation process and the final (120 h) biofilm wet weight. The results were shown in a way of mean value \pm standard deviation $(n=3)$. $(A)$ Biofilm wet weight development on stripe pattern surfaces. (B) Biofilm wet weight development on cube pattern surfaces. (C) $120 \mathrm{~h}$ biofilm wet weight on stripe pattern surfaces. (D) $120 \mathrm{~h}$ biofilm wet weight on cube pattern surfaces. The results indicated that the $1 \mu \mathrm{m}$ and $2 \mu \mathrm{m}$ surfaces inhibited biofilm growth significantly, and surfaces with pattern sizes larger than $10 \mu \mathrm{m}$ showed no significant inhibitory effect. For the two micro-pattern shapes, there was no significant difference between each other.

$180 \times 139 \mathrm{~mm}(300 \times 300 \mathrm{DPI})$ 

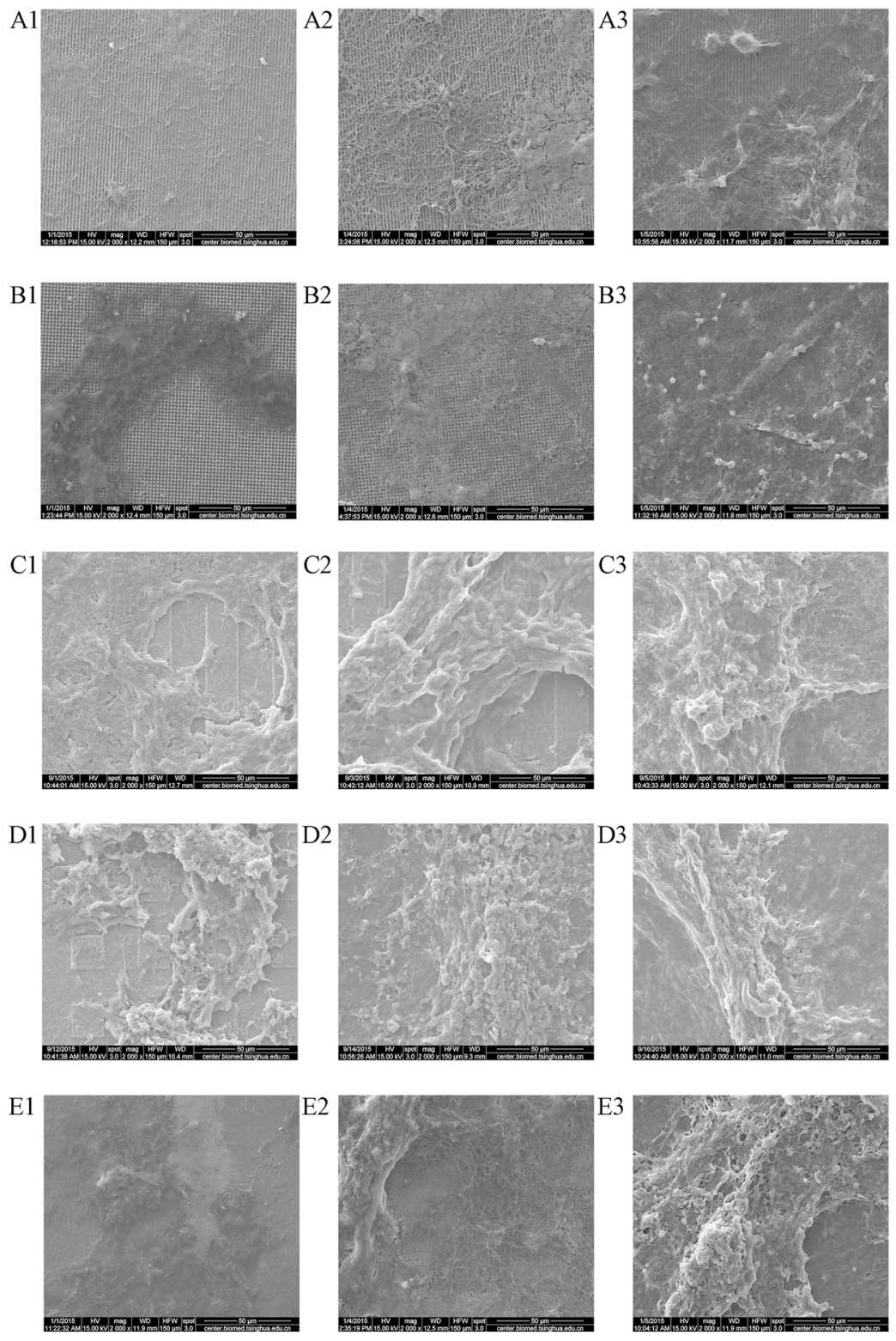

Figure 5. SEM pictures illustrating the micro-structures of the biofilms. A1-A3, $24 \mathrm{~h}, 72 \mathrm{~h}$ and $120 \mathrm{~h}$ biofilms on $1 \mu \mathrm{m}$ stripe surfaces; B1-B3, $24 \mathrm{~h}, 72 \mathrm{~h}$ and $120 \mathrm{~h}$ biofilms on $1 \mu \mathrm{m}$ cube surfaces; C1-C3, 24 h, 72 h and $120 \mathrm{~h}$ biofilms on $20 \mu \mathrm{m}$ stripe surfaces; D1-D3, $24 \mathrm{~h}, 72 \mathrm{~h}$ and $120 \mathrm{~h}$ biofilms on $20 \mu \mathrm{m}$ cube surfaces; E1-E3, $24 \mathrm{~h}, 72 \mathrm{~h}$ and $120 \mathrm{~h}$ biofilms on control group surfaces. At $24 \mathrm{~h}, 72 \mathrm{~h}$ and $120 \mathrm{~h}$, thicker and more inhomogeneous biofilms were observed on the $20 \mu \mathrm{m}$ and control group surfaces, compared to the biofilms on the $1 \mu \mathrm{m}$ surfaces. The $1 \mu \mathrm{m}$ surfaces significantly inhibited bacteria settlement and the subsequent biofilm formation. Scale bar (on the right lower corner of each figure) $=100 \mu \mathrm{m}$.

$$
131 \times 191 \mathrm{~mm}(300 \times 300 \mathrm{DPI})
$$



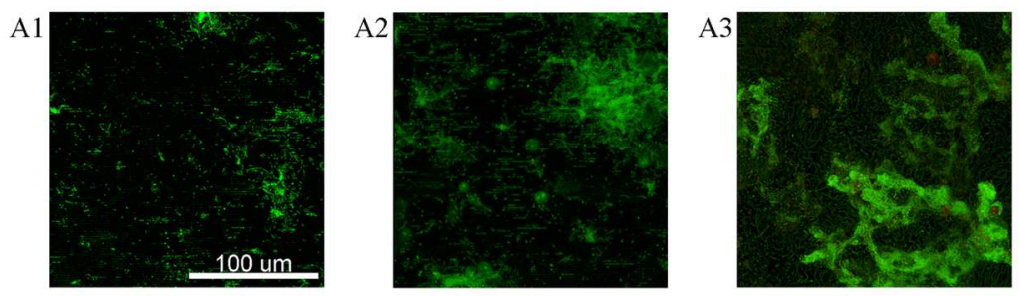

B1
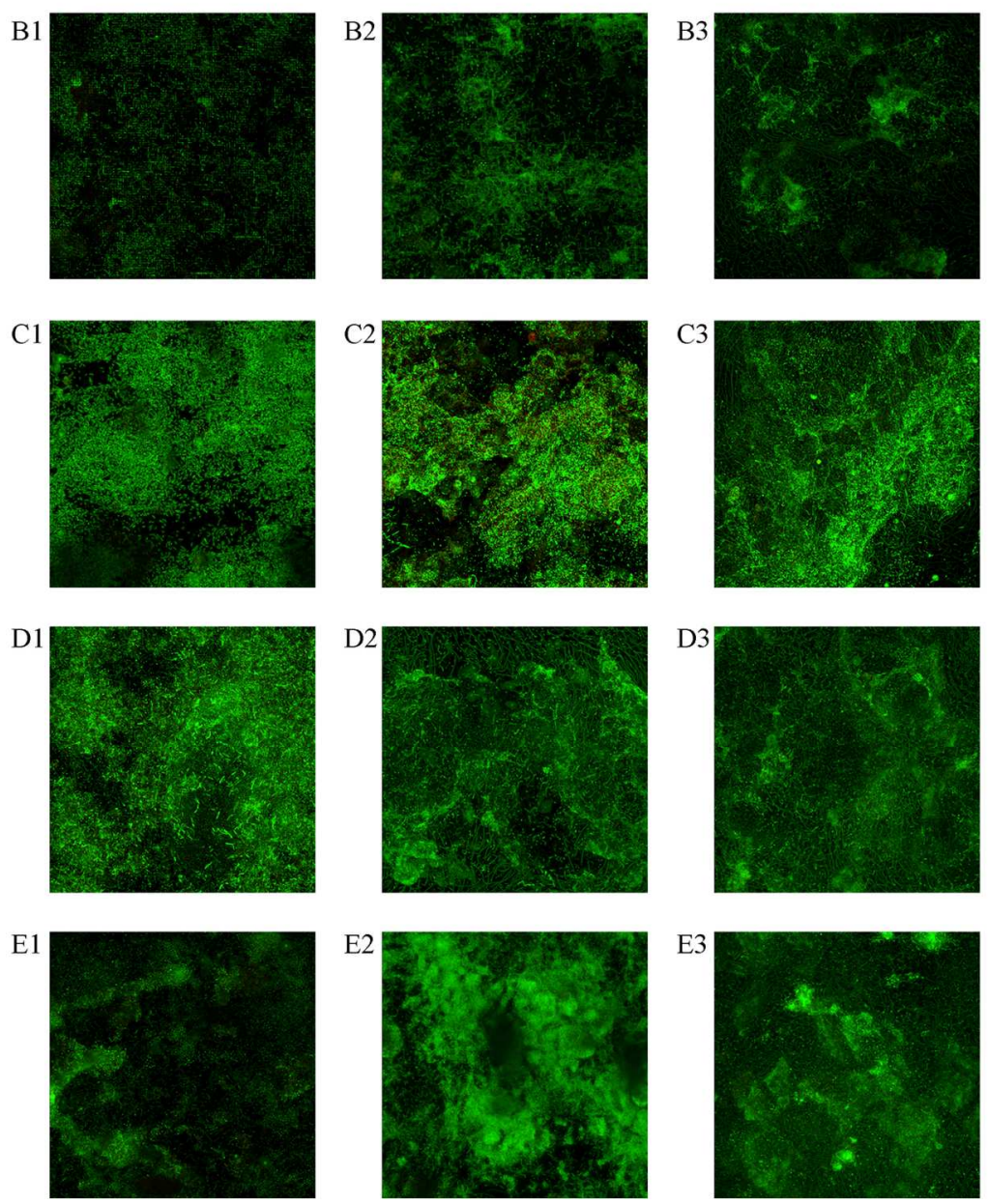

Figure 6. CLSM pictures illustrating the micro-structures and the cell viability of the biofilms. A1-A3, $24 \mathrm{~h}, 72$ $\mathrm{h}$ and $120 \mathrm{~h}$ biofilms on $1 \mu \mathrm{m}$ stripe surfaces; B1-B3, $24 \mathrm{~h}, 72 \mathrm{~h}$ and $120 \mathrm{~h}$ biofilms on $1 \mu \mathrm{m}$ cube surfaces; C1-C3, $24 \mathrm{~h}, 72 \mathrm{~h}$ and $120 \mathrm{~h}$ biofilms on $20 \mu \mathrm{m}$ stripe surfaces; D1-D3, $24 \mathrm{~h}, 72 \mathrm{~h}$ and $120 \mathrm{~h}$ biofilms on 20 $\mu \mathrm{m}$ cube surfaces; E1-E3, $24 \mathrm{~h}, 72 \mathrm{~h}$ and $120 \mathrm{~h}$ biofilms on control group surfaces. Green fluorescence indicated live bacteria cells. Red fluorescence, though could hardly be observed, indicated dead bacteria cells. The structural development of the biofilms showed a similar trend illustrated in Fig. 5 . Most of the bacteria cells settled to the bottom of the patterns and the outline of the patterns could be seen in $A 1$, $A 2$, B1 and B2. The majority of cells were live cells (green fluorescence), indicating the micro-patterned surfaces showed no bactericidal effect. Scale bar (on the right lower corner of A1) $=100 \mu \mathrm{m}$. 

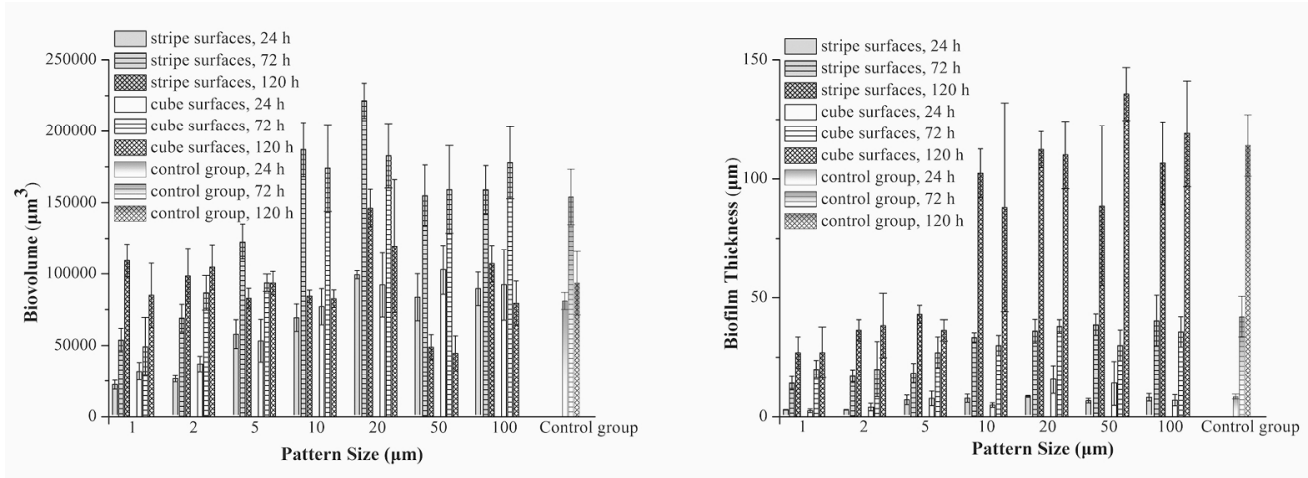

Figure 7. Quantitative analysis of the $24 \mathrm{~h}, 72 \mathrm{~h}$ and $120 \mathrm{~h}$ biofilm CLSM pictures. (A) Biovolume (B) Biofilm thickness. The results were shown in a way of mean value \pm standard deviation $(n=5)$. The biovolume and biofilm thickness on $1 \mu \mathrm{m}$ and $2 \mu \mathrm{m}$ surfaces were significantly decreased. For the two pattern shapes, there was no significant difference between each other.

$180 \times 68 \mathrm{~mm}(300 \times 300$ DPI $)$ 

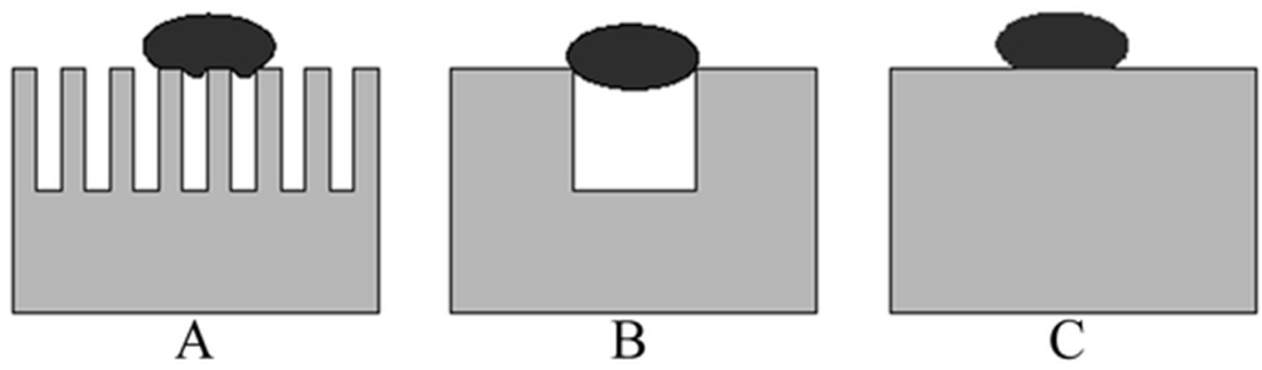

Figure 7. Quantitative analysis of the $24 \mathrm{~h}, 72 \mathrm{~h}$ and $120 \mathrm{~h}$ biofilm CLSM pictures. (A) Biovolume (B) Biofilm thickness. The results were shown in a way of mean value \pm standard deviation $(n=5)$. The biovolume and biofilm thickness on $1 \mu \mathrm{m}$ and $2 \mu \mathrm{m}$ surfaces were significantly decreased. For the two pattern shapes, there was no significant difference between each other.

$51 \times 14 \mathrm{~mm}(300 \times 300 \mathrm{DPI})$ 